\title{
CORRECTION
}

\section{Genetic risk of Parkinson disease and progression: An analysis of 13}

longitudinal cohorts

Neurol Genet 2019;5:e354. doi:10.1212/NXG.0000000000000354

In the article "Genetic risk of Parkinson disease and progression: An analysis of 13 longitudinal cohorts" by Iwaki et al., ${ }^{1}$ first published online July 9, 2019, in the abstract's results, the phrase should be "T allele of rs114128760." The authors regret the error.

\section{Reference}

1. Iwaki H, Blauwendraat C, Leonard HL, et al. Genetic risk of Parkinson disease and progression: An analysis of 13 longitudinal cohorts. Neurol Genet 2019;5:e348. 


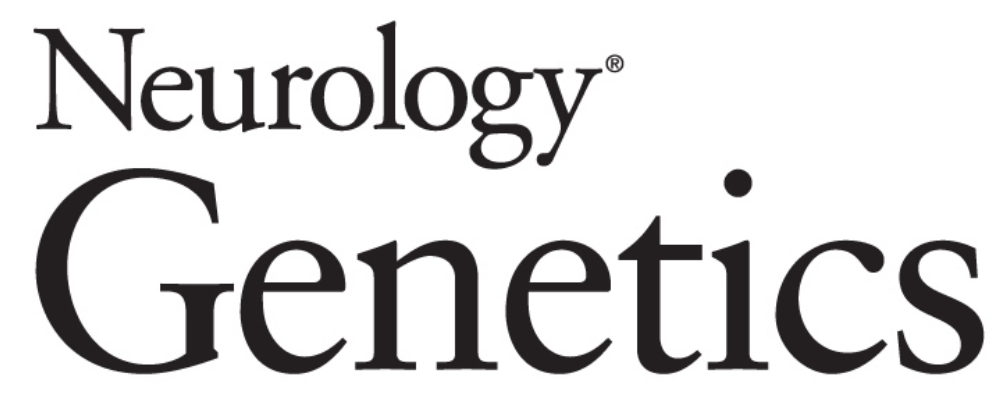

\section{Genetic risk of Parkinson disease and progression: An analysis of 13 longitudinal cohorts \\ Neurol Genet 2019;5; \\ DOI 10.1212/NXG.0000000000000354}

This information is current as of August 15, 2019
Updated Information \&
including high resolution figures, can be found at:
Services
http://ng.neurology.org/content/5/4/e354.full.html
References
This article cites 1 articles, 1 of which you can access for free at: http://ng.neurology.org/content/5/4/e354.full.html\#\#ref-list-1
Permissions \& Licensing its entirety can be found online at:
http://ng.neurology.org/misc/about.xhtml\#permissions
Reprints
Information about ordering reprints can be found online: http://ng.neurology.org/misc/addir.xhtml\#reprintsus

Information about reproducing this article in parts (figures,tables) or in

Neurol Genet is an official journal of the American Academy of Neurology. Published since April 2015, it is an open-access, online-only, continuous publication journal. Copyright @ 2019 American Academy of Neurology. All rights reserved. Online ISSN: 2376-7839.

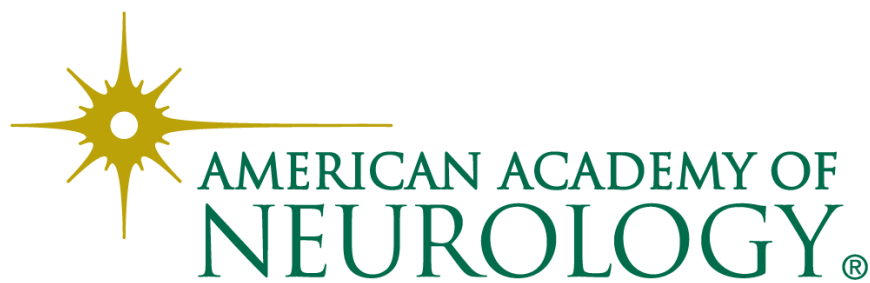

